\title{
PERAN KEPALA SEKOLAH DALAM MENCIPTAKAN \\ BUDAYA RELIGIUS SISWA STUDI KASUS DI SEKOLAH DASAR NEGERI GRENJENG KOTA CIREBON
}

\author{
Novianti Muspiroh \\ Staf pengajar Institut Agama Islam Negeri Syekh Nurjati Cirebon \\ noviantimuspiroh.ak@gmail.com
}

\begin{abstract}
Abstrak
Tujuan penelitian ini adalah untuk mendeskripsikan secara mendalam peran kepala sekolah dalam menciptakan budaya religius siswa: studi kasus di Sekolah Dasar Negeri Grenjeng Kota Cirebon. Penelitian ini ialah penelitian kualitatif deskriptif. Sumber data berasalah dari kepala sekolah, guru-guru, para siswa, orang tua siswa dan masyarakat umum. Alat pengumpulan data meliputi wawacara mendalam, observasi mendalam, dan dokumentasi. Analisis data dilakukan melalui pengumpulan data, reduksi data, display data dan konklusi data. Hasil penelitian menunjukkan bahwa (1) Wujud budaya agama di Sekolah Dasar Negeri Grenjeng meliputi: (a) pembelajaran baca tulis al-Qur'an (BTQ), (b) Pembiasaan sikap senyum dan salam, (c) Pelaksanaan shalat berjamaah, (d) pemakaian jilbab (berbusana muslim), (e) peringatan hari-hari besar Islam (PHBI). (2) strategi kepala sekolah dalam mengembangkan budaya agama meliputi: (a). Perencanaan progam, (b) Memberi teladan kepada warga sekolah. (2) Penciptaan budaya religius di sekolah berdampak kepada sikap religius siswa di rumah dalam kehidupan sehari-hari. Peran kepala sekolah dalam menjalankan program sekolah berbasis Islam di SDN Grenjeng diwujudkan dalam peran sebagai pemimpin, manajer, pendidik, inovator, administrator, dan supervisor.
\end{abstract}

Kata kunci: pengaruh, peniruan, aktivitas positif, pembiasaan

\section{A. Latar Belakang Masalah}

Pendidikan adalah kebutuhan hidup manusia sepanjang hayatnya, baik sebagai individu, kelompok sosial, maupun sebagai bangsa. Pendidikan sudah terbukti dapat mengembangkan sumber daya manusia yang merupakan karunia Allah SWT, serta memiliki kemampuan untuk mengembangkan nilai-nilai kemanusiaan, sehingga kehidupan manusia semakin beradab (Fadjar, 1998: 53).

Pendidikan sejatinya merupakan proses pembentukan moral masyarakat beradab, masyarakat yang tampil dengan wajah kemanusiaan dan pemanusiaan yang normal. Artinya, pendidikan yang dimaksudkan di sini lebih dari sekedar sekolah (education not only education as schooling) melainkan pendidikan sebagai jaring-jaring kemasyarakatan (education as community networks). Pendidikan diharapkan bisa memberikan sebuah kontribusi positif dalam membentuk manusia yang memiliki keseimbangan antara kemampuan intelektual dan moralitas. Dengan mensejajarkan dua komponen ini pada posisi yang tepat, diharapkan bisa mengantarkan kita untuk menemukan jalan yang lurus, shirat almustaqim. Jalan yang akan dapat membuka mata hati dan kesadaran kemanusiaan kita sebagai anak-anak bangsa. Sehingga krisis yang hampir saja menghempaskan kita ke jurang kebangkrutan dan kehancuran, dengan segera dapat dilalui dan cepat berlalu. 
ini $\begin{array}{cc}\text { Krisis moral yang melanda bangsa } \\ \text { nampaknya menjadi sebuah }\end{array}$ kegelisahan bagi semua kalangan. Bagaimana tidak dari maraknya kasus korupsi yang tidak pernah surut bahkan mengalami peningkatan dari waktu ke waktu. Di sisi lain krisis ini menjadi komplek dengan berbagai peristiwa yang cukup memilukan seperti tawuran pelajar, penyalahgunaan obat terlarang, pergaulan bebas, aborsi, penganiayaan yang disertai pembunuhan. Fenomena ini sesungguhnya sangat berseberangan dengan suasana keagamaan dan kepribadian bangsa Indonesia. Jika krisis ini dibiarkan begitu saja dan berlarut-larut apalagi dianggap sesuatu yang biasa maka segala kebejatan moralitas akan menjadi budaya. Sekecil apapun krisis moralitas secara tidak langung akan dapat merapuhkan nilai-nilai kehidupan berbangsa dan bernegara.

Realitas tersebut mendorong timbulnya berbagai gugatan terhadap efektifitas pendidikan agama yang selama ini dipandang oleh sebagian besar masyarakat telah gagal. Kegagalan pendidikan agama ini disebabkan karena praktik pendidikannya hanya memperhatikan aspek kognitif semata dari pertumbuhan nilai-nilai (agama), dan mengabaikan pembinaan aspek afektif dan konatif-volitif, yakni kemauan dan tekad untuk mengamalkan nilai-nilai ajaran agama.

Krisis tersebut bersumber dari krisis moral, akhlak (karakter) yang secara langsung atau tidak langsung berkaitan dengan pendidikan. Krisis karakter yang dialami bangsa saat ini disebabkan oleh kerusakan individu-individu masyarakat yang terjadi secara kolektif sehingga menjadi budaya. Budaya inilah yang menginternal dalam sanubari masyarakat Indonesia dan menjadi karakter bangsa. Ironis, pendidikan yang menjadi tujuan mulia justru menghasilkan output yang tidak diharapkan.

Pendidikan moral menjadi sangat penting bagi teguh dan kokohnya suatu bangsa. Pendidikan moral adalah suatu proses panjang dalam rangka mengantarkan manusianya untuk menjadi seorang yang memiliki kekuatan intelektual dan spiritual sehingga dapat meningkatkan kualitas hidupnya di segala aspek dan menjalani kehidupan yang bercita-cita dan bertujuan pasti. Hal ini harus menjadi agenda pokok dalam setiap proses pembangunan bangsa. Pendidikan moral ini bisa diaplikasikan pada penanaman nilai-nilai agama di sekolah. Pengembangan nilai-nilai agama dalam komunitas sekolah madrasah sudah pasti adanya karena madrasah merupakan sekolah tingkat dasar berbasis agama yang mempunyai kurikulum berdominasi progam-progam keagamaan dibawah naungan departemen agama yang mempunyai landasan kokoh yang normatif religius dan konstitusional. Dalam hal ini bukan berarti sekolah dasar berbasis umum dibawah naungan dinas pendidikan dan kebudayaan tidak menanamkan nilai-nilai agama. Sekolah dasar berbasis umum lebih menekankan pada aspek ilmu yang bersifat umum tetapi tetap menanamkan nilai-nilai agama melalui pendidikan agama Islam sebagai alat pembentukan moral.

Pendidikan agama yang syarat dengan pembentukan nilai-nilai moral (pembentukan afeksi) di sekolah umum, hanya memperhatikan aspek kognitif semata dari pertumbuhan kesadaran nilainilai (agama), dan mengabaikan pembinaan aspek afektif dan konatifvolitif, yakni kemauan dan tekad untuk mengamalkan nilai-nilai ajaran agama. Pengajaran agama yang berorientasi kognitif semata hanyalah sekedar pengalihan pengetahuan tentang agama. Pengalihan pengetahuan agama memang dapat menghasilkan pengetahuan dan ilmu dalam diri orang yang diajar, tetapi pengetahuan ini belum menjamin pengarahan seseorang untuk hidup sesuai dengan pengetahuan tersebut. Oleh sebab itu, pengajaran agama menghasilkan pengetahuan hafalan yang melekat di bibir dan hanya mewarnai kulit, tetapi tidak 
mampu mempengaruhi orang yang mempelajarinya.

Masalah pendidikan termasuk pendidikan agama merupakan kewajiban dan tanggungjawab semua pihak, baik sekolah, lingkungan masyarakat, ataupun lingkungan rumah harus secara bersamaan mengemban amanah pendidikan. Dalam konteks sekolah, pendidikan merupakan tanggungjawab kepala sekolah dan warga sekolah untuk mendidik dan membina moral peserta didik.

Dalam konteks Indonesia, berdasarkan Undang-Undang Nomor 20 Tahun 2003 Tentang Sistem Pendidikan Nasional Pasal 3 pendidikan nasional berfungsi mengembangkan kemampuan dan membentuk watak serta peradaban bangsa yang bermartabat dalam rangka mencerdaskan kehidupan bangsa, bertujuan untuk berkembangnya potensi peserta didik agar menjadi manusia yang beriman dan bertaqwa kepada Tuhan Yang Maha Esa, berakhlak mulia, sehat, berilmu, cakap, kreatif, mandiri, dan menjadi warga negara yang demokratis serta bertanggung jawab.

Melihat fenomena di atas maka solusi yang ditawarkan adalah pengembangan nilai-nilai religius di lembaga pendidikan. Berdasarkan studi pendahuluan yang kami lakukan di Sekolah Dasar Negeri (SDN) Grenjeng. SDN Grenjeng merupakan salah satu sekolah dasar yang menerapkan progam yang mendukung penanaman nilai-nilai Islam, dengan tujuan agar mampu meningkatkan dan memperkokoh nilai ketauhidan, pengetahuan agama dan pratik keagamaan siswa yang berada di lingkungan rendah sadar agama. Sehingga pengetahuan agama yang diperoleh di sekolah tidak hanya dipahami saja sebagai sebuah pengetahuan akan tetapi bagaimana pengetahuan itu mampu diterapkan dalam kehidupan sehari-hari. Karena dengan tertanamnya nilai-nilai budaya religius pada diri siswa akan memperkokoh imannya dan aplikasinya nilai-nilai keIslaman tersebut dapat tercipta dari lingkungan di sekolah. Untuk itu membangun budaya religius sangat penting dan akan mempengaruhi sikap, sifat dan tindakan siswa secara tidak langsung. Berdasarkan data yang kami dapat melalui studi pendahuluan, hal ini menarik untuk ditindaklanjuti.

\section{B. Tinjauan Teori}

Sekolah adalah lembaga yang bersifat kompleks dan unik. Bersifat kompleks karena sekolah sebagai organisasi yang di dalamnya terdapat berbagai dimensi yang satu sama yang lain saling berkaitan dan saling menentukan. Sedangkan sifat uniknya adalah menunjukkan bahwa sekolah sebagai organisasi memiliki ciri-ciri tertentu yang tidak dimiliki oleh organisasi-organisasi lain. Ciri-ciri yang menempatkan sekolah memiliki karakter tersendiri, di mana terjadi proses belajar mengajar, tempat terselenggaranya pembudayaan kehidupan manusia (Wahdjosumidjo, 2007: 81). Karena sifatnya yang kompleks dan unik itulah, sekolah sebagai organisasi memerlukan tingkat kordinasi yang tinggi. Keberhasilan sekolah adalah keberhasilan kepala sekolah.

Kepala sekolah yang berhasil adalah apabila mereka memahami keberadaan sekolah sebagai organisasi yang kompleks dan unik, serta mampu melaksanakan peranannnya sebagai seorang yang diberi tanggungjawab untuk memimpin sekolah. Beberapa kepala sekolah digambarkan adalah orang yang mempunyai harapan tinggi bagi para staf dan siswa, kepala sekolah adalah mereka yang banyak mengerti tugas-tugas mereka dan meraka yang menentukan irama bagi sekolah mereka (Lipham, 1985: 1560).

Kepala sekolah memiliki peran yang sangat penting terhadap pendidikan di sekolah. Hal ini dibuktikan dalam banyak riset. Penelitian di negara bagian Texas menemukan bahwa kepala sekolah memiliki dampak yang sangat besar terhadap prestasi siswa (Branch, Hanushek, dan Rivkin, 2013: 62-69). 
Pemimpin sekolah yang efektif telah terbukti secara signifikan meningkatkan kinerja semua siswa di sekolah, setidaknya sebagian melalui dampaknya pada seleksi dan retensi guru yang baik. Kepala sekolah yang tidak efektif memiliki efek negatif yang sama besar pada kinerja sekolah (DeMatthews dan Mawhinney, 2014: 844881).

Berdasar hal di atas menunjukkan betapa penting peranan kepala sekolah dalam menggerakkan kehidupan sekolah dalam mencapai tujuan. Ada dua hal yang harus diperhatikan dalam paparan di atas. Hal ini adalah: (1) kepala sekolah berperan sebagai kekuatan sentral yang jadi kekuatan penggerak kehidupan sekolah. (2) kepala sekolah harus memahami tugas dan fungsinya demi keberhasilan sekolah, serta memiliki kepenulian kepada staf dan para siswa.

Ada dua kata kunci yang dapat dipakai sebagai landasan untuk memahami lebih jauh tugas dan fungsi kepala sekolah. Kedua kata tersebut adalah "kepala" dan "sekolah". Kata kepala dapat diartikan ketua atau pemimpin dalam suatu organisasi atau sebuah lembaga di mana menjadi tempat menerima dan memberi pelajaran (Departemen Pendidikan dan Kebudayaan Republik Indonesia. 1988: 420-796). Dengan demikian secara sederhana kepala sekolah dapat didefinisikan sebagai seorang tenaga fungsional guru yang diberi tugas untuk memimpin suatu sekolah di mana diselenggarakan proses belajar mengajar, atau di mana terjadi interaksi antara guru yang memberi pelajaran pada murid, dan murid yang menerima pelajaran.

Kata memimpin mengandung makna luas, yaitu kemampuan untuk menggerakkan sumber yang ada pada suatu sekolah sehingga dapat didayagunakan secara maksimal untuk mencapai tujuan yang telah ditetapkan.Dalam praktik organisasi kata memimpin mengandung konotasi menggerakkan, mengarahkan, membimbing, melindungi, membina, memberi teladan, memberikan dorongan, memberi bantuan dan lain sebagainya. Betapa banyak variabel arti yang terkandung dalam kata memimpin atau pemimpin hal itu memberi indikasi bahwa betapa luas tugas dan peranan kepala sekolah sebagai seorang pemimpin organisasi dan lembaga pndidikan (Wahdjosumidjo, 2007: 83).

Adapun peran kepala sekolah dalam kepemimpinan adalah kepribadian dan sikap aktifnya dalam mencapai tujuan. Mereka aktif, berani membentuk ide, kepala sekolah dalam hal ini cenderung mempengaruhi perubahan suasana hati, dan tepat pada tujun keinginan khusus yang ditetapkan untuk urusan yang terarah. Hasil kepemimpinan ini mempengaruhi perubahan cara orang berfikir tentang apa yang dapat diinginkan, dimungkinkan dan diperlukan.

Melihat perkembangan sekolah yang semakin kompleks tersebut, maka peran kepala sekolah hendaknya tidak hanya sebagai pemimpin pembelajaran (instructional leadership), namun harus berupaya untuk mengelola sekolah dalam konteks yang lebih luas, yakni sekolah sebagai tempat proses pendidikan yang melibatkan banyak elemen masyarakat yang berkepentingan didalamnya. Sehingga sekolah hendaknya mempunyai sistem yang baik untuk menunjang berhasilnya dan berlangsungnya proses tersebut dengan kondisi lingkungan dalam hal ini lingkungan sekolah yang menjamin pencapaian kualitas yang diharapkan.

Menurut Kyte (1972) sebagai kepala sekolah memiliki lima funsi dan peranan utama. Pertama, bertanggug jawab atas keselamatan, kesejahteraan, dan perkembangan murid-murid di lingkungan sekolah. Kedua, tanggung jawab atas kesejahteraan dan keberhasilan profesional guru, ketiga berkewajiban memberikan layann sepenuhnya yang berharga bagi murid-murid dan guru-guru yang memungkinkan dilakukan melalui pengawasan resmi, bertanggung jawab mendapatkan bantuan mksimal dari semua 
instusi pembantu, kelima, bertanggung jawab untuk mempromosikan murid-murid terbaik melalui berbagai cara (Kyte, 1972).

\section{Metode Penelitian}

Sugiyono (2007: 12) membedakan pendekatan penelitian menjadi pendekatan kuantitatif dan kualitatif. Pendekatan yang digunakan dalam penelitian kami adalah pendekatan kualitatif deskriptif. Karena kita hanya menggunakan satu variabel dalam penelitian, dan data yang diperoleh adalah berupa informasi-informasi dan pendapat mengenai program berbasis Islam pada sekolah dasar umum sebagai upaya penanaman sikap religius siswa SDN Grenjeng. Adapun pengertian penelitian kualitatif menurut Kurniawan (2017: 24) adalah penelitian yang datanya adalah data kualitatif sehingga analisisnya juga analisis kualitatif atau penggambaran temuan lapangan yang nutaralistik atau apa adanya sesuai dengan kondisi lapangan. Penelitian mencari makna dari semua data yang tersedia, dan penelitian deskriptif adalah suatu penelitian yang dilakukan dengan tujuan utama untuk memberikan gambaran atau deskripsi tentang suatu keadaan secara objektif. Jadi dapat disimpulkan bahwa penelitian kualitatif deskriptif adalah penelitian dengan pencarian data apa adanya atau naturalistik sesuai dengan kondisi lapangan atau secara objektif yang digambarkan secara mendalam dengan satu variabel.

Penelitian mengenai peran kepala sekolah dalam menerapkan program berbasis Islam pada sekolah dasar umum sebagai upaya penanaman pembiasaan sikap religius ini peneliti lakukan di SDN Grenjeng yaitu di jn. P. Grenjeng No. 32 Kelurahan Harjamukti, Kecamatan Harjamukti, Kota Cirebon, Provinsi Jawa Barat. Sekolah tersebut kami pilih setelah kami melakukan pertimbangan dengan melakukan studi pendahuluan sebelumnya. Dengan melakukan studi pendahuluan terlebih dahulu kami akan mendapatkan gambaran lebih jelas untuk mendapatkan permasalahan yang terjadi. Untuk alasan lebih jelasnya peneliti memilih lokasi penelitian ini adalah SDN Grenjeng merupakan salah satu dari sekolah dasar umum yang menerapakan program sekolah berbasis Islam.

Penelitian dilakukan dari Oktober 2017 sampai Juni 2018. Data yang kami dapat diperoleh melalui observasi mendalam, wawancara mendalam, dan dokumentasi. Sumber data yang kami dapatkan melalui observasi atau pengamatan yakni bertempat di SDN Grenjeng adapaun sumber data yang kami dapatkan yang peroleh melalui wawancara yaitu dengan narasumber dari beberapa guru, siswa dan orang tua siswa SDN Grenjeng dan sumber data yang diperoleh melalui dokumentasi yaitu dengan memotret area lingkungan sekolah.

Validasi data penelitian ini yaitu dilakukan melalui kredibilitas triangulasi waktu dan sumber dan melakukan perpanjangan pengamatan agar peneliti dan narasumber semakin akrab dan semakin terbukti, sehingga tidak ada informasi yang disembunyikan. Selain itu juga kami melakukan pengumpulan data dengan waktu yang relatif lama serta strategi multi metode (kombinasi teknik pengumpulan data dengan wawancara. Observasi dan dokumentasi. Teknik analisis data yaitu dengan melakukan pengumpulan data, reduksi data, display datadan penarikan kesimpulan.

\section{Temuan}

1. Penciptaan Budaya Religius di SDN Grenjeng

SDN Grenjeng merupakan sekolah umum yang bercirikhas Islam, hal tersebut dapat dilihat dari budaya sekolah yang mengedepankan budaya agama Islam didalamnya. Tujuan yang di gaungkan SDN Grenjeng adalah menghasilkan lulusan yang kuat, cerdas, terampil, berbudi luhur, dan bertaqwa kepada tuhan yang maha Esa. Tujuan selanjutnya adalah membangun sumber daya unggul sebagai sarana bersaing lembaga baik di tingkat 
nasional maupun internasional (Dok./BD/05 Oktober 2017).

Untuk membangun citra dan keunggulan suatu lembaga pendidikan mutlak diperlukan strategi yang solid yang mencakup strategi peningkatan mutu pendidikan dan SDM unggul serta pengembangan budaya agama sebagai ciri khas SDN Grenjeng. Oleh sebab itu harus dilaksanakan dalam programprogram kongkrit yang dilakukan secara konsisten dengan komitmen tinggi dari semua unsur lembaga pendidikan yang ada di SDN Grenjeng yang mencakup guru, siswa, karyawan serta kepala sekolah (Dok./BD/05 Oktober 2017).

Penciptaan budaya religius merupakan suatu program yang di dalamnya terdapat nilai-nilai Islam, dimana jika program berbasis Islam ini terlaksana dengan baik maka akan berpengaruh terhadap sikap siswa dalam melaksanakan kehidupan seharihari seperti yang dicantumkan dalam tujuan. Bukan hanya kepala sekolah yang berperan akan tetapi anggota dalam sekolah yaitu guru dan staff juga ikut serta atas himbauan dari kepala sekolah untuk mendukung keberhasilan program yang direncanakan.

Berdasarkan pengamatan dan wawancara secara langsung dengan kepala sekolah, guru, dan siswa di SDN Grenjeng, dapat peneliti paparkan hasil penelitian yang peneliti dapatkan diantaranya adalah yang pertama tentang budaya agama di SDN Grenjeng. Budaya yang ada dan berkembang di SDN Grenjeng meliputi: pembelajaran BTQ dilakukan setiap satu minggu sekali sesuai dengan jadwal pembelajaran di setiap kelas, sekaligus dengan pembacaaan doa sehari-hari. Untuk pelaksanaan shalat duhur berjamaah yaitu dilaksanakan pada hari selasa sampai hari kamis dan dilakukan secara bergiliran untuk siswa kelas atas yaitu kelas 4, 5 dan 6. Pada hari jumat dan sabtu tidak dilaksanakan karena pulang lebih cepat dari hari biasanya atau belum waktu duhur, memperingati harihari besar Islam (PHBI), dan pembiasaan salam dan sapa. Pelaksanaan pembacaan asmaul husna dilakukan setiap hari secara bersama-sama dan dilanjut dengan membersihkan lingkungan sekolah (setiap siswa mengambil sampah yang terlihat berserakan).

Hal ini sesuai dengan hasil wawancara dengan Sugiarti selaku kepala SDN Grenjeng. Dia mengungkapkan bahwa:

"Saya ingin melihat warga sekolah ini berprilaku islami sesuai norma dan ajaran agama terlebih pada siswa, untuk itu saya tekankan kepada seluruh siswa muslimah dianjurkan memakai jilbab setiap harinya, shalat jum'at berjamaah, memperingati hari-hari besar Islam, pembelajaran baca tulis al-Qur'an dan berakhlaqul karimah dengan pembiasaan salam, sapa, senyum sebagai budaya agama di SDN Grenjeng ini “ (WW/KS/BA/05 Oktober 2017).

Dari ungkapan kepala sekolah disebutkan bahwa pemakaian jilbab, berbusana muslim, pembelajaran seni baca al-Qur'an, serta pembiasaan senyum, salam, sapa adalah salah satu dari budaya yang ada di SDN Grenjeng, hal itu sesuai yang dipaparkan oleh Sugiarti, yaitu:

"Budaya agama di SDN Grenjeng ini memang benar adanya, selain dari pemakaian wajib berjilbab yang sudah menjadi ketentuan dari sekolah, sebenarnya masih banyak cerminan budaya agama yang ada disini seperti halnya wajib melaksanakan shalat berjamaah, dan hidupnya kegiatan-kegiatan Islami oleh siswa" (WW/GR/BA/05 November 2017). 
Budaya agama di SDN Grenjeng berjalan sangat baik karena ada beberapa aktifitas di sekolah yang sangat islami dan hal tersebut berjalan baik. Budaya agama di sekolah ini meliputi beberapa macam cerminan juga simbol-simbol yang bisa secara nampak dilihat dan diamati bersama, hal ini sesuai yang dipaparkan oleh salah seorang guru dalam wawancara penulis, dia berkata:

Banyak hal yang bisa dilihat secara nampak terhadap budaya yang ada di sekolah saya ini, diantaranya adalah pemakaian jilbab. Saat ini pengembangannya masih terpengaruh oleh budaya teknologi sehingga anak-anak masih lebih cenderung enjoy main internet, asyik dengan bermain laptop. Sehingga anak-anak masih enggan melaksanakan kegiatan agama yang ada di sekolah ini. Akan tetapi usaha sekolah selalu menjaring mereka untuk ikut serta dan melaksanakan kegiatan keislaman sebagai aplikasi terhadap budaya agama yang ada di sekolah ini, sehingga saya rasa pengembangan budaya agama di sekolah ini tetap berjalan dengan baik dan efektif “ (WW/SSW/BA/07 Desember 2017).

Budaya agama di sekolah ini bisa terlihat dari sikap dan prilaku siswasiswi, guru-guru, karyawan dan semua warga sekolah yang ada. Budaya agama di sekolah ini terbangun karena komitmen semua warga sekolah, dan adanya kebijakan kepala sekolah yang secara tertulis dan tidak sudah dipahami dan dilaksanakan oleh semua warga sekolah. Hal tersebut sesuai yang dipaparkan guru pendidikan agama Islam, beliau berkata:

Budaya agama di sekolah ini menurut saya adalah suatu rutinitas yang dilaksanakan oleh semua warga sekolah yang ada budaya agama di sekolah ini adalah dalam bentuk kegiatan yang ada dan dilaksanakan oleh siswa di lingkungan sekolah ini serta dukungan warga/komunitas sekolah yang ada. Seperti: shalat jamaah setiap hari, shalat jumat berjamaah di mushola, berqurban dan berzakat, peka terhadap masalah sosial misalnya melakukan bakti sosial dan lain-lain, bentuk lainnya adalah mempengaruhi siswa untuk menghormati guru, sesama siswa dan semua warga sekolah hal ini dilakukan dengan berjabat tangan dan mengucapkan salam ketika bertemu." Desember 2017).

Dari beberapa macam budaya agama yang ada di SDN Grejneng Kota Cirebon, budaya agama tersebut dapat di pahami dari penjelasan sebagai berikut:

a. Program pembelajaran Baca Tulis alQur'an

Program pembelajaran Baca Tulis al-Qur'an (BTQ) adalah kegiatan pembelajaran membaca dan menulis yang ditekankan pada upaya memahami informasi, tetapi ada pada tahap menghafalkan, lambang-lambang dan mengadakan pembiasaan dalam melafalkannya serta cara menuliskannya. Adapun tujuan dari pembinaan dan pembelajaran baca tulis al-Qur'an ini adalah agar dapat membaca kata-kata dengan kalimat sederhana dengan lancar dan tertib serta dapat menulis huruf dan lambanglambang Arab dengan rapih, lancar dan benar. Selain itu, bukan hanya untuk menjadikan siswa tahu tetapi dapat menjadikan siswa mengerti dan memahami konsep-konsep tersebut dan menghubungkan suatu konsep dengan konsep lain dan mampu mengaplikasikan dan mendasari kegiatan sehari-hari yang dilakukannya berdasarkan ajaran al-Qur'an. Dalam hal ini, ibu Sugiarti merencanakan juga adanya sertifikat dari sekolah bagi 
siswa yang lulus dalam pembelajaran BTQ.

Dengan adanya program BTQ diharapkan siswa memiliki kemampuan membaca dan menulis al-Qur'an, karena menurut penuturan Ibu Sugiarti bahwa di kelas atas masih ada siswa yang belum bisa memahami huruf hijaiyah dengan benar. Tujuan pengajaran baca tulis al-Qur'an adalah membina manusia secara pribadi dan kelompok sehingga mampu membaca dan menulis al-Qur'an serta mampu menjalankan fungsinya sebagai hamba Allah dan khalifah-Nya guna membangun dunia sesuai dengan konsep yang ditetapkan oleh al-Qur'an. Selain itu juga, adanya pembelajaran doa sehari-hari, metode pembiasaan merupakan metode yang paling efektif diterapkan dalam proses menghafal doa harian untuk siswa di Pendidikan Anak Usia Sekolah Dasar. Metode ini dirasa paling ringan karena tidak ada unsur pemaksaan pada anak, anak dikenalkan pada satu doa yang kemudian dibaca secara berulang-ulang yang menjadikan anak terbiasa mendengar sehingga si anak menjadi hafal dengan sendirinya.

Program pembelajaran baca tulis al-Qur'an (BTQ) di SDN Grenjeng merupakan progam wajib yang diperuntukkan bagi seluruh siswa. Pembelajaran baca tulis al-Qur'an ini dimasukkan dalam satu rumpun pembelajaran pengembangan diri yang kedua pembelajaran tersebut dimasukkan dalam penilaian raport siswa.

Pembelajaran baca tulis alQur'an, sebagai salah satu budaya yang ada di SDN Grenjeng dan merupakan rumpun pelajaran dari bidang pengembangan diri yang wajib diikuti oleh semua siswa, mempunyai tujuan agar seluruh siwa yang berada di SDN Grenjeng bisa lancar membaca alQur'an dan yang lebih penting tindakan dan prilaku siswa berdasarkan pada ajaran al-Qur'an.
Berkaitan dengan pembelajaran baca tulis al-Qur'an (BTQ), Sugiarti selaku kepala sekolah mengungkapkan bahwa:

Adanya pembelajaran seni baca alQur'an di SDN Grenjeng adalah mempunyai satu tujuan yang akan kami capai yaitu agar seluruh siswa yang berada di SDN Grenjeng bisa lancar membaca al-Qur'an dan yang lebih penting tindakan dan prilaku siswa berdasarkan pada ajaran alQur'an" (WW/KS/BA/05 Januari 2018).

Lebih lanjut kepala sekolah juga mengungkapkan bahwa salah satu tujuan diadakannya pengembangan diri pembelajaran seni baca al-Qur'an, dimaksudkan agar sekolah yang notabennya adalah sekolah umum seperti halnya dengan SDN Grenjeng, agar bisa menyamai/sejajar bahkan mempunyai nilai lebih baik dibandingkan dengan madrasah pada umumnya. Hal ini ditegaskan oleh kepala sekolah dalam wawancara peneliti sebagai berikut:

Banyak fenomena sekarang anakanak dari sekolah umum kurang bisa membaca al-Qur'an dengan lancar dan baik, padahal dia adalah seorang muslim. Oleh karenanya saya rasa penting SDN Grenjeng mewajibkan seluruh siswa mengikuti pembelajaran baca tulis al-Qur'an. Selain agar bisa membaca dengan baik juga lulusan SDN Grenjeng bisa sejajar/menyamai siswa madrasah ibtidaiyah bahkan kalau bisa mempunyai nilai lebih baik dari madrasah" (WW/KS/BA/05 Desember 2017).

Ungkapan diatas didukung oleh pernyataan seorang guru, yaitu mengungkapkan bahwa:

Di zaman yang semakin moderen ini, semua siswa, terlebih siswa 
yang berasal dari sekolah umum dalam hal ini SDN Grenjeng diharapkan mampu mendidik anakanak dengan baik, dan yang lebih penting anak sekolah harus bisa membaca al-Qur'an dengan baik jangan sampai lulus SDN tidak bisa membaca, diharapkan lulusan SDN Grenjeng bisa sejajar dengan madrasah ibtidaiyah bahkan lebih mempunyai nilai yang positif" (WW/GR.WAKASIS/BA/06

September 2017).

Adanya pembelajaran baca tulis alQur'an menurut hasil wawancara peneliti bertujuan agar siswa SDN Grenjeng bisa bersaing dengan madrsah yang diharapkan lulusan SDN Grenjeng bisa membaca al-Qur'an dengan baik dan benar serta dapat mengamalkan ajaran al-Qur'an sebagai landasan dalam berprilaku sehari-hari. Dan pembelajaran baca tulis al-Qur'an sebagai rumpun pembelajaran pengembangan diri merupakan salah satu wujud dari budaya agama di SDN Grenjeng.

b. Pemakaian Wajib Berjilbab

Pemakaian jilbab merupakan tindak lanjut dari pengembangan budaya agama yang digagas oleh kepala sekolah di SDN Grenjeng. Pemakaian jilbab diharapkan secara langsung dapat melatih siswa berprilaku Islami dan berakhlakul karimah sebagai atribut dirinya untuk menjadi seorang yang berpribadi muslim. Mengenai hal ini Sugiarti selaku kepala sekolah menjelaskan bahwa:

Dengan adanya pemakaian jilbab (berbusana muslim/muslimah) pada hari jum'at dan pada bulan ramadhan diharapkan secara langsung dapat melatih siswa berprilaku Islami dan berakhlakul karimah sebagai atribut dirinya untuk menjadi seorang yang berpribadi muslim/muslimah (WW/KS/BA/05 Nopember 2017).
Di SDN Grenjeng ini menurut adalah lain dari pada SD pada umumnya, karena meskipun berciri khas sekolah umum tetapi lingkungan sekolah terwujud budaya agama yang memang dikembangkan dan dilaksanakan serta berusaha dipertahankan.

Salah satu yang membedakan dengan sekolah lain adalah lingkungan sekolah, lingkungan sekolah di SDN Grenjeng terasa lain karena di sana hidup budaya agama seperti halnya pemakaian wajib. Hal ini sesuai yang diungkapkan oleh Sugiarti: "Yang menjadikan SDN Grenjeng berbeda dengan sekolah lainnya adalah suasana lingkungan yang ada, disini hidup budaya agama seperti halnya pemakaian wajib berjilbab" (WW/GR/BA/07 November 2017).

Pemakaian jilbab adalah salah satu budaya agama yang berkembang di SDN Grenjeng, dan semua warga sekolah menjalankan serta melaksanakannya dengan baik dan penuh tanggungjawab. Hal tersebut terlihat ketika peneliti secara langsung mendatangi tempat penelitian (SDN Grenjeng) pada tanggal 17 Juli 2017 sewaktu peneli melihat pemakaian wajib berjilbab (Ob./Ba/17 Juli 2017).

Pemakaian jilbab dan berbusana muslim juga dilaksanakan oleh warga sekolah dengan baik serta penuh tanggungjawab. Hal ini sesuai observasi yang dilakukan peneliti pada tanggal 15 Oktober 2017 sewaktu peneliti melihat secara langsung busana siswa di bulan ramadhan yang lalu (Ob./Ba/15 Oktober 2017).

c. Pelaksanaan Shalat Berjamaah

Pelaksanaan shalat bersama di sekolah adalah salah satu budaya agama di SDN Grenjeng, pelaksanaan shalat berjamaah dimaksudkan untuk memperkuat tali silaturrahim dan mempersatukan ikatan emosional antara kepala sekolah dengan warga sekolah, 
antara guru dan siswa, antara siswa dengan sesama siswa serta seluruh karyawan yang ada.

Pernyataan tersebut diungkapkan oleh kepala sekolah, Sugiarti sebagai berikut:

Penting bagi SDN Grenjeng untuk melaksanakan shalat berjamaah di sekolahan, shalat jum'at yang dilaksanakan di sekolahan mempunyai banyak hikmah salah satunya adalah memperkuat tali silaturrahim dan mempersatukan ikatan emosional antara kepala sekolah dengan warga sekolah, antara guru dan siswa, antara siswa dengan sesama siswa serta seluruh karyawan yang ada" (WW/KS/BA/07 Mei 2018).

Senada dengan apa yang diungkapkan kepala sekolah, dengan shalat berjamaah di sekolah dapat mempererat hubungan antar warga sekolah. Siwa dengan siswa juga terlihat akrab, dan terjadi hubungan komunikasi yang harmonis.

Hal ini di dukung oleh pernyataan salah satu siswa kelas enam bernama Mahmud yang berhasil peneliti wawancarai. Dalam pernyataannya dia memaparkan bahwa:

Setelah saya mengikuti shalat berjamaah di sekolah, saya merasakan hal menyenangkan sekali. Karena saya akan bertemu temanteman saya dari kelas lain dan bertemu guru-guru saya, setelah shalat berjamaah biayasanya kami berdiskusi dengan teman-teman juga guru. Jadi dengan adanya shalat berjamaah ini saya merasakan dapat mempererat hubungan komunikasi harmonis antar warga sekolah, siswa dengan siswa, siswa dengan guru dan kepala sekolah dengan guru maupun siswa" (WW/KS/BA/10 Mei 2018).
Pemaparan dari Mahmud selaku siswa kelas enam SDN Grenjeng diperkuat dari ungkapan Sugiarti, yang memberi penjelasan bahwa:

Pelaksanaan shalat berjamaah sangat penting dan harus dilaksanakan di sekolah ini karena dengan shalat berjamaah yang dilaksanakan di sekolah akan dapat menambah keakraban dan kerukunan antara sesama warga sekolah, selain itu dengan adanya shalat berjamaah disini agar mushola ini juga dapat difungsikan dengan baik" (WW/GR/BA/07 Mei 2018).

Adapun pelaksanaan dari shalat berjamaah dilaksanakan secara bergantian pada tiap minggunya. Hal itu disebabkan karena keterbatasan tempat/mushola yang hanya bisa menampung $80 \%$ dari jumlah keseluruhan siswa yang ada.

d. Pembiasaan Senyum dan Salam

Ciri khas yang dimiliki oleh SDN Grenjeng adalah Pembiasaan senyum dan salam, hal ini merupakan pengembangan budaya agama yang dipertahankan dan dikembangkan oleh sekolah. Pembiasaan senyum dan salam merupakan sebuah tahapan dari budaya agama yang dikembangkan sebagai proses penanaman nilai-nilai Islam dalam pribadi muslim. budaya senyum dan sapa di SDN Grenjeng bertujuan agar siswa memiliki tatakrama (akhlaq) yang baik, guru juga memiliki sikap saling menghargai terhadap sesama, kepala sekolah juga menghargai semua guru, karyawan serta siswa.

Pernyataan diatas diungkapkan kepala sekolah kepada peneliti:

Budaya senyum dan sapa adalah ciri khas kita sebagai umat Islam dan hal itu berusaha saya terapkan di SDN Grenjeng, tujuan saya adalah agar siswa memiliki tatakrama (akhlaq) yang baik, guru juga memiliki sikap saling menghargai terhadap sesama, 
dan saya juga lebih bisa menghargai guru-guru, siswa, dan karyawan yang ada" (WW/KS/BA/05 Mei 2018).

Dari Pembiasaan senyum dan salam terlihat nuansa Islam yang hidup dan berkembang di SDN Grenjeng. Pembiasaan senyum dan salam di SDN Grenjeng ditekankan kepada seluruh siswa-siswi yang baru bergabung di sekolah ini. Dimaksudkan agar sejak dini siswa bisa mengikuti budaya yang sudah dilaksanakan oleh warga SDN Grenjeng.

Pembiasaan senyum dan sapa dibudayakan dan diperkenalkan setiap aktivitas pembelajaran. Sikap tersebut ditekankan dari awal, selanjutnya prilaku itu berjalan dengan sendirinya, hal ini terbukti dari siswa yang duduk dikelas dua dan tiga tetap membudayakan kebiyasaan senyum dan sapa. Budaya senyum dan sapa adalah wajib dan berlaku untuk semua warga sekolah di SDN Grenjeng.

Dalam observasi yang peneliti lakukan sikap senyum dan salam dipraktekkan langsung siswa kepada saya. Pada waktu peneliti tiba di sekolah, ada salah seorang siswa yang menyapa dengan senyum: "Assalamualaikum....., serentak saya menjawab waalaikum salam....dan bertanya: apakah hari ini sekolah masih aktif?..." (Ob./Ba/14 Mei 2018).

Sikap senyum dan sapa sudah menjadi rutinitas semua warga sekolah. Dengan adanya pembiasaan senyum dan sapa melatih siswa dan guru serta semua warga sekolah untuk hidup saling menghargai sesama. Hal ini seperti di ungkapkan oleh Arif salah satu siswa kelas enam yang mengatakan bahwa:

"Saya merasakan sekolahan saya ini lain dengan sekolah-sekolah pada umumnya, sekolah ini terasa seperti madrasah ibtidaiyah karena suasana madrasah bisa saya rasakan di sekolah saya ini. Sekolah ini sangat menjaga nilai-nilai Islam. Salah satu yang dapat saya rasakan adalah setiap bertemu dengan guru dan sesama siswa saya dianjurkan untuk menyapa dan mengucap salam, dan hal itu sudah saya lakukan semenjak saya duduk di kelas satu dengan adanya budaya ini, melatih saya untuk hidup saling menghargai" (WW/SW/BA/14 Mei 2018).

e. Peringatan Hari-Hari Besar Agama Islam (PHBI)

Budaya agama di sekolah ini tidak hanya wajib shalat berjamaah, pemakaian jilbab pada waktu mengikuti pembelajaran pendidikan agama Islam, mengucap salam, berpakaian sopan dan berbusana muslim, dan berprilaku sopan santun kepada semua warga sekolah, akan tetapi salah satu pengembangan budaya yang ada adalah peringatan PHBI pada hari-hari besar agama Islam.

Salah satu contoh dari peringatan hari-hari besar (PHBI) sebagai budaya agama yang ada di SDN Grenjeng adalah nampak terlihat ketika bulan Ramadhan selama 15 hari penuh siswa wajib memakai busana muslim/muslimah dan mengikuti pesantren Ramadhan yang selain diisi dengan materi-materi agama juga diisi oleh beberapa perlombaan Islami yang dapat menambah semangat siswa untuk menjalankan ibadah puasa serta meningkatkan rasa iman dan taqwa siswa, hal ini selaras dengan yang diungkapkan oleh Sugiarti, dia mengungkapkan bahwa:

Pada bulan Ramadhan selama 15 hari mengikuti kegiatan pesantren Ramadhan dan wajib mendengarkan mauidhah hasanah yang mendatangkan ustad dari luar. Untuk ukuran sekolah umum adanya pesantren ramadan saya tahu tidak semua sekolah mengadakan. Pada bulan 
Ramadhan siswa-siswi dari kelas satu dan dua selalu melaksanakan kegiatan keislaman tahun kemarin dan sekarang siswa-siswi mengadakan beberapa perlombaan seperti lomba adzan, seni baca alQur'an, lomba berpidato, lomba nasyid, yang pesertanya adalah semua siswa-siswi kelas satu dan dua" (WW/GR/BA/12 Juni 2018).

Apa yang diungkapkan oleh Sugiarti dibuktikan oleh peneliti dalam observasi di lapangan yang melihat secara langsung kegiatan di bulan Ramadhan. Adanya perlombaan serta kegiatan pesantren Ramadhan memang terlaksana dengan baik. Hal ini sesuai dengan pengamatan peneliti pada tanggal 16 Juni sewaktu peneliti mengamati acara perlombaan dan pesantren Ramadhan SDN Grenjeng (Ob/Ba/16 Juni 2018).

Kegiatan hari besar Islam lainnya yang dilaksanakan di sekolah adalah menyembelih qurban pada hari raya Idul Adha. Pada hari itu semua guru, karyawan dan siswa berkumpul di sekolah untuk memperingati hari raya Idul Adha dan menyembelih qurrban. Hal ini sesuai dengan ungkapan kepala sekolah bahwa:

Ketika tiba hari raya qurban, wajib bagi sekolah untuk menyembelih hewan qurban, dan saya selaku kepala sekolah mewajibkan seluruh warga sekolah untuk merayakan bersama di sekolah dengan menyembelih qurban yang nantinya di bagikan kepada warga yang ada di sekita lingkungan sekolah" (WW/KS/BA/16 Juni 2018).

Tujuan diadakannya penyembelihan hewan qurban adalah sebagai wahana siswa untuk bisa memotivasi diri gemar bersedekah dengan memberikan sebagian harta kepada fakirmiskin, dan melatih siswa mempunyai pribadi yang bersosial terhadap masyarakat.

Dari beberapa peringatan harihari besar PHBI yang telah dilaksanakan di sekolah, dapat mengembangkan budaya agama dan melatih warga sekolah untuk selalu tanggap dan melaksanakan peringatan hari-hari besar Islam.

Dari beberapa hasil wawancara peneliti baik dengan kepala sekolah, dewan guru dan sebagian siswa yang peneliti wawancarai, semua berpendapat dan mengatakan hal yang sama terhadap budaya agama di SDN Grenjeng, bahwa budaya agama di SDN Grenjeng berkembang dan dilaksanakan serta dipertahankan oleh warga sekolah yang ada, budaya agama di sekolah ini meliputi: penambahan ekstra pengembangan diri baca tulis al-Qur'an yang wajib diikuti oleh siswa-siswi yang berada di kelas satu, penanaman sikap salam jika bertemu siapa saja di sekolah ini, pelaksanaan shalat berjamaah, pemakaian wajib berbusana muslim, peringatan hari-hari besar Islam (PHBI) salah satu contoh meliputi peringatan di bulan Ramadhan wajib melaksanakan pesantren Ramadhan.

2. Sikap religius siswa di rumah dalam kehidupan sehari-hari

Sikap seseorang dapat dipengaruhi oleh kebiasaan dan teman terdekatnya, oleh karena itu kepala sekolah SDN Grenjeng melaksanakan program berbasis Islam agar siswa mempunyai akhlakul karimah, dan mampu menjalankan tugasnya sebagai makhluk ciptaan Allah SWT sebagaimana manusia diciptakan sebagai khalifah untuk dapat menjaga bumi dan seiisinya dengan baik bukan malah merusak sesuai dengan yang terjadi pada saat ini.

Pembiasaan sikap religius anak yang paling utama dipengaruhi oleh orang tua di rumah, yang kami temukan 
berdasarkan interaksi wawancara dengan orang tua siswa SDN Grenjeng kesadaran beragamanya kurang. Hal ini juga merupakan salah satu latar belakang dibuatnya progam berbasis Islam.

Dalam penelitian yang penulis lakukan, penulis mendapatkan data melalui wawancara dengan beberapa orang tua siswa yaitu bapak Dedi ayah dari Tegar siswa kelas 2 SDN Grenjeng mengutarakan bahwa Tegar selalu antusias untuk mengaji dan melaksanakan shalat, berdo'a sebelum melakukan kegiatan sehari-hari seperti makan dan tidur. Ibu Suneni ibu dari Harfif Faqih siswa kelas 3 SDN Grenjeng mengutarakan bahwa dalam melaksanakan kehidupan sehari-hari Harfif selalu bersikap sopan dengan selalu berpamitan ketika akan berangkat sekolah tetapi masih sungkan melakukan shalat. Ibu Sumiyati, ibu dari Nafis siswa kelas 3 SDN Grenjeng mengutarakan Nafis selalu antusias mengaji dan selalu bersikap sopan tetapi dalam melaksanakan shalat masih malas, hal ini dikarenakan lingkungan keluarga yang kurang religius sehingga berdampak pada sikap siswa. Ibu Neneng, ibu dari Nisa Nur A mengutarakan bahwa Nisa siswi kelas 5 SDN Grenjeng selalu berdo'a dalam melakukan kegiatan kehidupan seharihari seperti makan, tidur, masuk WC dan lain-lain, antusias mengaji dan lebih rajin melaksanakan shalat. Ibu dari Amel siswi kelas 5 SDN Grenjeng, Amel selalu bersikap sopan, lebih antusias mengaji tetapi dalam pelaksanaan shalat masih belum konsisten.

3. Peran kepala sekolah dalam menjalankan program sekolah berbasis Islam di SDN Grenjeng

Budaya agama yang ada di SDN Grenjeng merupakan gagasan dari kepala sekolah, hal ini dimaksudkan agar sekolah yang notabennya umum bisa sejajar dengan madrasah ibtidaiyah bahkan lebih baik dalam hal pengembangan nilai agama Islam. Dalam pengembangan budaya agama di sekolah ini kepala sekolah merupakan figur yang pertama memberikan tauladan kepada semua warga sekolah.

Budaya agama sendiri menurut kepala sekolah mempunyai makna prilaku seseorang yang mempunyai nilai ibadah sebagai pondasi dan sebagai salah satu landasan dalam menjalankan agama Islam, karena budaya agama Islam sebagai pondasi dan landasan dalam menjalankan agam Islam, maka penting budaya agama ini dilaksanakan, dikembangkan dan dipertahankan di sekolah ini, budaya agama yang kepala sekolah gagas dan sudah dijalankan oleh semua warga sekolah adalah memakai jilbab dan berbusana muslim.

Dalam penelitian yang kami lakukan, kami mendapatkan data melalui wawancara bahwa program sekolah berbasis Islam di SDN Grenjeng sudah berjalan selama satu tahun yang dibuat oleh kepala sekolah. Kepala sekolah menerapkan Program berbasis Islam yang terdiri dari pembelajaran BTQ, pembacaaan doa sehari-hari, pembacaan asmaul husna di setiap pagi sebelum melaksanakan pembelajaran, shalat berjamaah dan pola hidup bersih. Penerapan program berbasis Islam sudah terlihat dari adanya pemasangan bingkai yang bertuliskan asmaul husna di setiap lorong sekolah, gambar-gambar bertuliskan kata-kata bernilai Islam seperti "kebersihan sebagian dari iman", "tiada kata seindah do'a", "dengan agama hidup menjadi terarah", hadits tentang menuntut ilmu, dan poster-poster panduan melakukan kegiatan dalam kehidupan sehari-hari sesuai dengan ajaran Islam dan lain sebagainya. Terlihat juga kebersihan lingkungan sekolah, kamar mandi yang 
bersih dan adanya jadwal piket harian yang diterapkan di setiap kelas.

Peran kepala sekolah dalam mengembangkan budaya agama bisa dilihat dari sikap kepala sekolah yang nampak seperti ada usaha untuk mengembangkan budaya agama, ada usaha kepala sekolah untuk mempertahankan budaya agama serta adanya usaha kepala sekolah untuk menjadikan sekolah dengan suasana Islami melalui budaya agama yang ada di SDN Grenjeng.

Dalam wawancara peneliti dengan kepala sekolah ketika peneliti menanyakan tentang peran kepala sekolah terhadap pengembangan budaya agama, beliau mengungkapkan bahwa:

"Untuk mengembangkan dan menjalankan budaya agama saya akui sulit, semua itu butuh proses, tetapi saya yakin jika kita berusaha pasti semua akan berhasil, saya tetap optimis pengembangan budaya agama di sekolah ini tahun demi tahun akan mengalami perubahan yang signifikan terlebih pada prilaku akhlak siswa akan mencerminkan nilai-nilai Islam, serta dapat melaksanakan ajaran dan syariat Islam dengan baik" (WW/KS/ DUK /20 Mei 2018).

Adapun peran kepala sekolah terhadap pengembangan budaya agama dapat dilihat juga dari loyalitas, semangat, prilaku sehari-hari serta saling mengingatkan dan saling memberi masukan kepada guru-guru terkait budaya agama yang ada di sekolah ini.

Pada prilaku misalnya, pada saat peneliti datang ke sekolah, peneliti masih di tempat parkir motor, tiba-tiba kepala sekolah keluar dari sebuah ruangan, beliau langsung menyapa dan senyum kepada saya sambil berkata: "Assalamualaikum...Bagaimana khabarnya bu....sambil bersalaman dengan saya. Ada yang perlu kami bantu.....terkait penelitian ibu....?" (Ob./ Duk /4 Oktober 2017)

Dengan sikap beliau yang terbuka kepada semua orang yang berada di lingkungan sekolah, hal ini menunjukkan salah satu bentuk dukungan kepala sekolah dalam mendukung pengembangan budaya agama di sekolah. Karena dalam pemaparan di atas dijelaskan salah satu dari budaya agama yang ada di SDN Grenjeng adalah budaya menyapa, mengucap salam dan bersalaman ketika bertemu.

Kepala sekolah sangat mendukung terhadap pengembangan budaya agama yang ada, hal ini diperkuat dengan pendapat salah seorang komite sekolah mengungkapkan:

"Saya merasakan kepala sekolah loyal terhadap tugas dan kewajibannya, terlebih dalam pengembangan budaya agama beliau sangat mendukung sekali. Bentuk peran beliau yang saya amati dan saya rasakan adalah dalam bentuk keikutsertaan beliau dalam setiap kegiatan keagamaan, beliau juga ramah mudah bergaul dengan siapa saja dan ketika bertemu dengan siapapun selalu tersenyum dan menyapa. Saya rasa itu adalah sikap dukungan beliau terhadap pengembangan budaya agam di sekolah" (WW/KTU/ DUK /4 Juli 2017).

Dari beberapa hasil wawancara di atas dapat dipahami bahwa kepala sekolah mempunyai dukungan yang tinggi terhadap pengembangan budaya agama di SDN Grenjeng.

a. Peran kepala sekolah sebagai pemimpin

\begin{tabular}{lcr}
\multicolumn{1}{c}{ Kepala } & sekolah & sebagai \\
pemimpin & harus & mampu \\
memberikan & petunjuk & dan \\
pengawasan meningkatkan & kemauan
\end{tabular}


tenaga kependidikan, membuka komunikasi dua arah dan mendelegasikan tugas. Seorang kepala sekolah juga harus mampu menggerakkan anggota orgnisasinya agar tercapainya sebuah tujuan yang telah direncanakan. Di SDN Grenjeng Ibu Sugiarti selaku kepala sekolah cukup mampu dalam memimpin sekolah terlihat dari bagaimana beliau mampu mewujudkan program yang telah direncanakan.

Pengembangan budaya agama juga dilakukan dengan memberikan motivasi sehingga nantinya siswa melakukan suatu pekerjaan di dasari dengan nilai agama dan muncul dari keinginannya untuk melaksanakan ajaran-ajaran agamanya.

b. Peran kepala sekolah sebagai manajer

Sebagaimana yang telah dikemukakan di atas bahwa selain sebagai pemimpin seorang kepala sekolah juga sebagai seorang manajer yang harus mau dan mampu mendayagunakan seluruh sumber daya sekolah dalam rangka mewujudkan visi, misi dan mencapai tujuan. Begitu pula di SDN Grenjeng kepala sekolah telah mengatur program-program yang diberikan pemerintah sekaligus program yang di buat oleh sekolah yaitu program berbasis Islam.

c. Peran kepala sekolah sebagai pendidik

Kepala sekolah di SDN Grenjeng dalam kaitan sebagai pendidik dalam pengembangan budaya agama, sementara yang peneliti amati kepala sekolah di SDN Grenjeng ini selalu menjadikan pribadinya sebagai teladan yang baik, artinya sebelum merubah dan menyuruh para guru, staf, dan siswa untuk melaksanakan aktifitas di sekolah dengan nuansa religius, terlebih dahulu kepala sekolah melaksanakannya. Jadi secara tidak langsung sikap dan tindakannya dapat di contoh oleh guru, staf dan siswa yang ada.

Kepala sekolah dalam pengembangan budaya agama sementara pengamatan peneliti yang didapat adalah dengan mebuat progam-progam keislaman seperti jamah shalat berjamaah di sekolah, pemakaian jilbab wajib bagi siswa muslim, penambahan muatan lokal seni baca al-Qur'an dan lain sebagainya yang sudah dipaparkan di atas.

Yang perlu diperhatikan oleh setiap kepala sekolah terhadap perannya sebagai pendidik, mencakup dua hal pokok yaitu sasaran atau kepada siapa perilaku sebagai pendidik itu diarahkan. Sedangkan yang kedua, yaitu bagaimana peranan sebagai pendidik itu dilaksanakan. Selain itu hal yang harus diperhatikan oleh kepala sekolah yakni bukan hanya mendidik di sekolah melainkan mengawasi kegiatan siswa di rumah dan harus sering berkomunikasi dengan wali murid agar mengetahui sejauh mana perkembangan siswa. Ibu sugiarti sebagai seorang kepala sekolah sekaligus sebagai pendidik yang memiliki kewajiban untuk mengunjungi rumah siswa yang bermasalah dan mengajaknya untuk kembali untuk bersekolah seperti biasanya, dan selalu menjalin komunikasi dengan orang tua. Sebagai pendidik juga tentunya harus menanamkan sikap-sikap yang baik, setiap ada siswa yang bermasalah kepala selalu memberikan nasihat kepada siswa dan memberikan punishment yang mendidik kepada siswanya, dan tentunya Ibu sugiarti bisa menjadi tauladan yang baik. 
d. Kepala sekolah sebagai inovator

Kepala sekolah sebagai inovator akan tercermin dari caracara ia melakukan pekerjaannya secara konstruktif, kreatif, delegatif, rasional, dan objektif, pragmatis, keteladanan, disiplin serta adaptel dan fleksibel. Kata Inovasi berbarti ada sesuatu hal yang baru yang belum pernah ada. Disini kepala sekolah SDN Grenjeng menciptakan inovasi baru dengan menciptakan program berbasis Islam yang bertujuan untuk menanamkan sikap religius siswa di rumah. Hal ini sangat menarik karena masih belum banyak dilakukan di sekolah dasar umum pada khususnya.

e. Kepala sekolah sebagai administrator

Sebagai administrator sekolah, kepala sekolah mempunyai tugas dan tanggungjawab melaksanakan fungsi-fungsi administrasi yang diterapkan ke dalam kegiatankegiatan sekolah yang dipimpinnya, seperti membuat rencana atau program tahunan, menyusun organisasi sekolah, melaksanakan pengoordinasian dan pengarahan, dan melaksanakan pengelolaan kepegawaian.

Kepala sekolah SDN Grenjeng mengadministrasi program berbasis Islam, bahkan beliau mempunyai rencana untuk membuat sertifikat untuk pembelajaran BTQ.

f. Kepala sekolah sebagai supervisor Kepala sekolah sebagai supervisi, maka ia harus mampu melakukan berbagai pengawasan dan pengendalian untuk meningkatkan kinerja tenaga kependidikan. Di SDN Grenjeng kepala sekolah mengawasi pelaksanaan program berbasis Islam serta menilai kinerja guru. Kepala sekolah merencanakan penempatan guru yang sesuai dengan usia dan keterampilan guru.
Dalam pelaksanaan program berbasis Islam, kepala sekolah SDN Grenjeng membuat, merencanakan, mengorganisasikan,

mengadministrasikan dan memantau pelaksanaan kegiatan bahkan beliau ikut serta dalam melakukan kegiatan tersebut. Selain itu peran kepala sekolah bertugas mengayomi anggotanya. Seperti yang diutarakan oleh ibu May selaku guru pembelajaran BTQ bahwa pada saat pembacaan asmaul husna beliau ikut serta dan yang penulis lihat di lain waktu beliau memberikan contoh yang baik seperti mengambil sampah yang berserakan dan membuangnya ke tempat sampah.

\section{E. Pembahasan}

Peran kepala sekolah dalam menerapkan program berbasis Islam di sekolah dasar umum sebagai upaya penanaman pembiasaan sikap religius siswa. Salah satu acuan indikator keberhasilan kepala sekolah di ukur dari mutu pendidikan yang ada di sekolah yang dipimpinnya. Sebaliknya juga keberhasilan sekolah ditentukan keprofesionalan kepala sekolah. Lebih lanjut seperti yang diungkapkan oleh Supriadi (2008: 346) bahwa "Erat hubungannya antara mutu kepala sekolah dengan berbagai aspek kehidupan sekolah seperti disiplin sekolah, iklim budaya sekolah, dan menurunnya perilaku peserta didik". Adanya program berbasis Islam di SDN Grenjeng dalam mengupayakan penanaman sikap religius siswa membuktikan bahwa kepala sekolah sangat memiliki mutu untuk memajukan sekolah. Selain itu juga kepala sekolah sangat berpengaruh terhadap pengelolaan pendidikan seperti pengelolaan mutu pendidikan, pengelolaan satuan unit pendidikan, pengelolaan administrasi, pengelolaan kurikulum, pengelolaan keungan pengelolaan antara sekolah dengan masyarakat, pengelolaan tenaga pendidik dan kependidikan dan pengelolaan peserta didik. 
Seperti yang kita ketahui bahwa peran kepala sekolah salah satunya adalah sebagai manajer, pendidik, motivator, administrator, dan supervisor yang merencanakan, melaksanakan dan mengevaluasi sebuah program yang ada di sekolah, bukan hanya peran-peran tersebut, kepala sekolah juga berperan sebagai pemimpin yang bertugas memimpin sekolah. Begitupula dalam hal ini, Ibu Sugiarti selaku kepala sekolah juga merencanakan, melaksanakan dan mengevaluasi program ini.

Berkaitan dengan kebiasaan ini, menurut Ahmad Amin (1998: 21) bahwa suatu perbuatan bila diulang-ulang sehingga menjadi mudah untuk dikerjakan ini disebut dengan adat kebiasaan. Dari pengertian tersebut bila dikaitkan dengan pendidikan dapatlah diambil suatu pelajaran bahwa kebiasaan itu merupakan suatu alat yang baik pula digunakan untuk mendidik anak, sehingga Islam pun menggunakannya sebagai metode mendidik. diharapkan dapat diterapkan dalam kehidupan sehari-hari siswa di rumah karena pada umumnya anak zaman sekarang kurang membiasakan membaca doa ketika hendak melakukan sesuatu.

Pembiasaan pembacaan Asmaul Husna dilakukan setiap pagi hari sebelum pembelajaran. Berbicara tentang Asmaul Husna mengundang suatu pendahuluan, yakni dengan mengingatkan bahwa fitrah insting keberadaan dalam diri setiap insan (Qurais Shihab, 1999:18). Disana tertampung berbagai emosi manusia seperti rasa takut, harap cemas, cinta, kesehatan, pengagungan, pencucian dan berbagai macam lainnya yang menghiasi jiwa manusia. Pembacaan asmaul husna dapat diartikan sebagai rutinitas suatu kegiatan yang dilakukan oleh seseorang secara tetap dengan tujuan untuk berdo'a memohon kepada Allah, maka kita akan memperoleh pahala, memperoleh ketenangan, memperoleh ketentraman kebahagiaan dan kemuliaan, memperoleh maghfirah, memperoleh kesuksesan, memperoleh pertolongan, terhindar dari musuh, aman dan selamat, hati menjadi tenang, disenangi oleh banyak orang dan masih banyak lagi khasiat-khasiat dan fadhillah-fadhillah dari asmaul husna. Progam pembacaan Asmaul Husna di SDN Grenjeng diharapkan dapat menanamkan nilai ketauhidan dalam diri siswa dan menjalankan kehidupan sehari-hari sesuai dengan ajaran Islam.

Pembiasaan shalat berjama'ah di SDN Grenjeng dilakukan dengan tujuan agar siswa dapat melaksanakan shalat tepat waktu dan timbul rasa persaudaraan yang ingin saling mengenal. Seperti yang telah dipaparkan dengan adanya shalat berjamaah diharapkan dapat timbulnya perasaan ukhuwah dan menambah semangat beribadah, dalam suasana teratur dibawah pimpinan seorang imam. Untuk itu dengan adanya program shalat berjamaah di sekolah ini, sekolah mengupayakan agar siswa di rumah juga dapat memiliki rasa kesaudaraan bukan hanya dengan keluarganya sendiri melainkan juga dengan orang lain dan terus melaksanakan shalat berjamaah di rumah.

Progam hidup bersih yang ditanamkan di SDN Grenjeng bertujuan untuk menciptakan lingkungan bersih dan sehat, kebersihan adalah upaya manusia untuk memelihara diri dan lingkungannya dari segala yang kotor dalam mewujudkan dan melestarikan kehidupan yang sehat dan nyaman. Kebersihan merupakan syarat bagi terwujudnya kesehatan, dan sehat adalah salah satu faktor yang dapat memberikan kebahagiaan. Sebaliknya kotor juga tidak saja merusak keindahan tetapi juga menyebabkan timbulnya berbagai penyakit, dan sakit merupakan salah satu faktor yang mengakibatkan penderitaan. Dalam Pustaka Media Syariah, ajaran kebersihan tidak hanya merupakan slogan atau teori belaka, tetapi harus dijadikan pola hidup praktis, yang mendidik manusia hidup bersih sepanjang masa, bahkan dikembangkan dalam hukum Islam, hal itu merupakan dasar dari tujuan penerapan hidup bersih di SDN Grenjeng 
yang diwujudkan dengan adanya jadwal piket rutin di setiap kelas, pembersihan lingkungan setelah pembacaan Asmaul Husna dan poster-poster himbauan kebersihan di sekitar sekolah. Demikian pula dengan penciptaan budaya religius melalui tegur, sapa, dan salam, program baca tulis al-Qur'an, perayaan hari besar Islam, dan penggunaan busana islami ikut memperkaya program tersebut.

\section{F. Kesimpulan}

Program berbasis Islam di SDN Grenjeng sebagian besar siswa memang sudah menanamkan sikap religius. Adanya progam berbasis Islam di SDN Grenjeng merupakan upaya kepala sekolah yang diwujudkan melalui pembelajaran BTQ, pembiasaan doa sehari-hari, pembacaan asmaul husna, shalat berjamaah dan berpakaian islami (jilbab), perayaan harihari besar Islam, tegur sapa salam dalam menanamkan sikap religius siswa yang tidak diterapkan di rumah dan mulai terhapuskan oleh perkembangan zaman. Program yang diterapkan juga tidak dapat dilepaskan dari peran kepala sekolah sebagai manajer, pemimpin, motivator, pendidik, administrator, dan supervisor yang telah merencanakan, melaksanakan dan mengevaluasi program tersebut.

\section{Referensi :}

Amin, Ahmad. 1998. Etika.Ilmu Akhlak. Jakarta : Bulan Bintang.

Branch, Gregory, Eric Hanushek, and Steven G. Rivkin, "School Leaders Matter: Measuring the impact of effective principals," dalam Education Next. 13 (1), Winter 2013: 62-69.
DeMatthews, David, dan Hanne Mawhinney. 2014. "Social Justice Leadership and Inclusion: Exploring Challenges in an Urban District Struggling to Address Inequities", dalam Educational Administration Quarterly. Vol 50, Issue 5, Dec 2014: 844-881.

Departemen Pendidikan dan Kebudayaan Republik Indonesia. 1988. Kamus Besar Bahasa Indonesia. Jakarta: Balai Pustaka.

Fadjar, A. Malik. 1998. Visi Pembaruan Pendidikan Islam. Jakarta: Lembaga Pengembangan Pendidikan dan Penyusunan Naskah Indonesia.

Kurniawan, Asep. 2017. Metodologi Penelitian Pendidikan. Cirebon: Eduvision.

Kyte, G.C., 1972. The Principal at work Rivised Edition. Boston: Gin and Company.

Lipham, James M., Robb E. Rankin, James A. Hoeh, Jr. 1985. The Principalship: Concepts, Competencies, and Cases. New York, N.Y.: Longman.

Shihab, Qurais. 1999. Membumikan AlQur'an, Fungsi dan Peran Wahyu dalam Masyarakat. Bandung: Mizan.

Sugiyono. 2007. Metode Penelitian Kuantitatif Kualitatif dan $R \& D$. Bandung: Alfabeta.

Supriadi, Dedi. 2008. Mengangkat Citra dan Martabat Guru. Yogyakarta: Adicita Karya Nusa.

Wahjosumidjo. 2007. Kepemimpinan Kepala Sekolah, Tinjauan Teoritik dan Permasalahannya. Jakarta: PT. Raja Grafindo Persada. 